\title{
SECOND LANGUAGE SPEECH: AN OUTLOOK TOWARDS CONTEMPORARY RESEARCH ENDEAVOURS
}

\section{A fala em segunda língua: Um panorama contemporâneo de pesquisas}

\author{
Alison Roberto GONÇALVES \\ Universidade Federal do Paraná \\ arg@ufpr.br \\ https://orcid.org/0000-0003-0959-7053 \\ Pedro Luis LUCHINI \\ Universidad Nacional de Mar del Plata \\ luchinipedroluis@gmail.com \\ https://orcid.org/0000-0002-7692-8361 \\ Rosane SILVEIRA \\ Programa de Pós-graduação em Inglês \\ Universidade Federal de Santa Catarina \\ Conselho Nacional de Pesquisa e Desenvolvimento Científico e Tecnológico \\ rosanesilveira@hotmail.com \\ https://orcid.org/0000-0003-0329-0376 \\ Ubiratã Kickhöfel ALVES \\ Programa de Pós-Graduação em Letras \\ Universidade Federal do Rio Grande do Sul \\ Conselho Nacional de Pesquisa e Desenvolvimento Científico e Tecnológico \\ ukalves@gmail.com \\ https://orcid.org/0000-0001-6694-8476
}

Interdisciplinarity has been an important component in the field of Second Language (L2) Speech. As stated by Colantoni, Steele and Escudero (2015), the task of understanding how L2 speech is perceived and produced has interested many researchers in different fields, such as Linguistics, Psychology, Education, Speech-language Pathology and Computer Science, among others. As a consequence of this interdisciplinary status, models of L2 speech perception and production are also grounded on different subfields of linguistics, such as Phonetics and Phonology, Language Acquisition and Psycholinguistics in general. Moreover, as we consider that new teaching methodologies are based on background knowledge concerning how new sound systems are learned, it

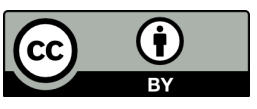


is also clear that L2 speech studies are of special interest not only to Formal, but also to Applied Linguistics.

In the Brazilian scenario, the two most common L2 speech models are the Speech Learning Model (SLM(-r), cf. FLEGE, 1995; FLEGE; BOHN, 2021) and the Perceptual Assimilation Model-L2 (BEST; TYLER, 2007). Although these two proposals share many assumptions, as both predict that L 2 sounds that are "similar" to L1 sounds are more easily assimilated to a native category, they are grounded on different backgrounds. The Speech Learning Model is based on a psychoacoustic view of perception, as it is more clearly stated in its revised version (FLEGE; BOHN, 2021). In turn, the PAM-L2 is grounded on a Direct, Realist view of speech perception (FOWLER, 1986), which has articulatory gestures (BROWMAN; GOLDSTEIN, 1986; 1992) as phonological primitives ${ }^{1}$. These features constitute different approaches to dealing with the same phenomenon, implying different epistemological views of Phonetics, Phonology, and Language Acquisition in general. In other words, each of these models faces distinct theoretical-methodological challenges to be overcome, giving rise to different research agendas aiming to expand their explanatory power, as well as their empirical validity.

Given these different research agendas and the challenges to be faced, researchers around the world are invited to contribute with theoretical discussions on the tenets of both the Speech Learning Model and the Perceptual Assimilation Model, considering the already-mentioned interdisciplinary status of these two proposals. In this volume, two papers aim to provide some contributions to these discussions: De Los Santos and Alves address the SLM, while Perozzo and Kupske discuss L2 speech perception in general, with a larger focus on Perozzo's (2017) approach to the PAM-L2.

De Los Santos and Alves discuss the possible attentional implications in bi/ multilingual phonetic-phonological development. The authors highlight that although attention has been undeniably seen as an important construct, there is still room for discussion on this construct in all L2 speech models. By concentrating on the progress made in the last thirty-five years by the Speech Learning Model, the authors discuss the methodological impact of considering the attentional construct associated with this model in bilingual speech studies.

In their article, Perozzo and Kupske address the connection of perception and production in L2 models. This is far from being considered a trivial issue, as the

1 In the Brazilian context, Perozzo (2017) proposes a revised version of the Perceptual Assimilation-Model, assuming an indirect, realist view of speech perception (JACKSON, 1977, 2010; LOWE, 1981; DANCY, 1985) and having acoustic-articulatory gestures (cf. ALBANO, 2001) as primitives of speech perception. 
perception-production link tends not to be addressed explicitly in many L2 models, and many of them do not even account for speech production. The authors argue that the connection between perception and production processes can be made viable with a gesture-driven perspective of L2 speech development, as gestures are phonological primitives that pervade and connect these two processes. By discussing the importance of implementing an acoustic-articulatory gestural account to language development, the authors rely on a phonological primitive that connects the processes of speech perception and production to a larger cognitive account. In other words, a gestural account should be able to bridge the gap between the abstract/cognitive and the physical components of speech perception and production.

These aspects considered, the two articles share one core assumption, which is explicitly stated in De los Santos and Alves' article: discussions aiming to broaden issues involving bi/multilingual cognition can theoretically and methodologically contribute to a greater understanding of the complex connection between L2 speech perception and production. Moreover, the two papers also share the prerogative, made explicit in Perozzo and Kupske, that it is imperative to discuss the phonological primitives of L2 speech models, as only then will theoreticians be able to account for both perception and production. Taken together, the two articles, therefore, provide insights from the fields of Psycholinguistics and Formal Linguistics to the discussions on L2 speech, making it clear that a larger understanding of the complex processes of speech perception and production demands a combined enterprise from different research backgrounds.

When it comes to the foci of language pedagogy, intelligible and comprehensible pronunciation needs to be at the forefront of L2 pronunciation teaching (LUCHINI; KENNEDY, 2013). For the last 20 years, L2 pronunciation research and pedagogy have been highly influenced by two opposing paradigms (LEVIS, 2005; 2018): The Nativeness principle, on the one hand, upholds the notion that L2 learners are likely to achieve a near native-like accent in their pronunciations. On the other hand, The Intelligibility principle refers to speech that listeners can comfortably understand despite having some traces of local or regional accent coming from the speaker's L1 (MUNRO; DERWING, 1999). Research has shown that The Nativeness principle's goal is at least unrealistic because achieving a nativelike pronunciation is physiologically conditioned after puberty (LENNEBERG, 1967; SCOVEL, 1995; IOUP et al., 1994; MOYER, 1999).

Although accent is sensitively evident, it hardly hinders understanding (DERWING; MUNRO 2009, 2015). Commonly, it is difficulties with intelligibility and/ or comprehensibility that may lead to misunderstandings. This indicates that the main 
aim for L2 pronunciation teaching should be to center on those pronunciation aspects that may impede understanding, unless the learner's speech is already very clear.

Most of the L2 pronunciation teaching materials focus on the development of certain segments (TROFIMOVICH; ISSAC, 2012). Although this decision may be valid, considering that sounds may contribute to the development of intelligibility, it relegates the role and importance that suprasegmentals have to achieve such a goal (MCNERNEY; MENDELSOHN, 1992; ORION, 1997). In fact, research has shown that prosodic features such as speech rate, fluency, stress, rhythm and intonation, to name a few, play a part in the development of comprehensibility (DERWING et al., 1998; GORDON et al., 2013; HAHN, 2004; ISAACS; TROFIMOVICH, 2012; KANG; JOHNSON, 2018; MCNERNEY; MENDELSOHN, 1992; SAITO; SAITO, 2017).

When we speak of pronunciation, we often refer to the quality and quantity of sounds and to the ability to decode those sounds on the part of the listener. From an acoustic, as well as articulatory perspective, the sounds form a kind of continuum in which there seems to be no intrinsic leaps, just a few grades and nuances. These segments are arranged along chains and organized into units or metric structures called intonation phrases, to which they are assigned a certain pitch contour. Levelt (1989) refers to the way in which phonetic representations are generated for the production of speech. This process involves much more than the mere concatenation of words retrieved from memory (GARCÍA JURADO; ARENAS, 2005).

From a cognitive perspective, both speaker and listener must be suitable for phonological encoding and decoding process in order to achieve fluent communication. This is where L2 pronunciation teachers assume a vital role, because they should carefully select those L2 phonetic-phonological aspects that they must teach and those that they can leave aside.

Within the scope of studies on second language acquisition, there seems to be a greater emphasis on research that explores segmentals at the expense of suprasegmentals (THOMSON; DERWING, 2015; LI; POST, 2014). Following this same line, Flege's Speech Acquisition/Learning Model (FLEGE, 1995; FLEGE; BOHN, 2021), as well as Best's Perceptual Assimilation Model (BEST, 1995; BEST; TYLER, 2007) emphasize on segmental aspects while offering little support for the understanding of the development of L2 prosody.

As for the different prosodic aspects that can be investigated, rhythm and nuclear stress placement seem to be the least explored (GUT, 2012; HAHN, 2004; LUCHINI, 2020; CUMMING, 2010; PANZACHI HEREDIA; LUCHINI, 2020). There is strong evidence 
that rhythm can influence communication, affecting levels of accent, intelligibility (SILVA JR.; BARBOSA, 2019) and comprehensibility (MUNRO; DERWING, 2001; LUCHINI, 2020; ORDIN; POLYANSKAYA, 2015). Rhythm can offer students acoustic clues to guide them through the segmentation process of language into prosodic units that perform numerous linguistic functions. For its part, nuclear stress is the protagonist of prosody. This prosodic feature plays a crucial role in producing textual cohesion and in sequencing the hierarchical organization of discourse. Nuclear stress highlights new and contrastive information and data that are not available for the listener to retrieve from the context or prior knowledge (BARDOVI-HARLIG, 1986; HALLIDAY, 2014; PENNINGTON; ROGERSON-REVELL, 2019). Many L2 learners have difficulty learning how to use nuclear stress in English. When nuclear stress is misplaced, sentence processing for the listener becomes more difficult, thus compromising comprehensibility (BIRCH; CLIFTON, 1995; KANG et al., 2010; TAJIMA et al., 1997; WINTERS; O'BRIEN, 2013). All said, rhythm and nuclear stress are undoubtedly important constructs that must be explored in the investigation of the acquisition of L2.

The current volume presents two articles that provide robust evidence that supports the view that explicit instruction of suprasegementals in the L2 pronunciation class contributes to increased intelligibility and comprehensibility.

Teixeira and Lima Jr. describe and discuss the development of the rhythm of English L2 by Brazilian students through three rhythmic metrics proposed for the rhythmic classification of languages. Their results demonstrate the value and usefulness of rhythmic metrics to describe the development of the L2 rhythm. They suggest expanding their inventory of rhythmic metrics, reference intervals and prominence correlates applied to their study to allow for a more precise characterization of rhythm development by Brazilian L2 learners from a more multidimensional perspective.

Delatorre and Silveira address the issue of intelligibility in English as a Lingua Franca contexts. They explored the intelligibility of regular verbs in the past produced by eight speakers of English whose first language (L1) were English, German, Spanish, or Brazilian Portuguese. Fourteen Brazilian learners of English participated as listeners and orthographically transcribed sentences produced by the speakers in two intelligibility tests. Findings of their study reveal that the number of intelligible verbs increased from the first to the second intelligibility test. They also point out that speakers' L1, listeners' lack of familiarity with speakers' accent and English pronunciation, as well as test conditions probably affected the intelligibility of verbs ending in -ed by Brazilian listeners. 
When it comes to pedagogical practices, textbooks that provide an overview of second language pedagogy often highlight that the teaching of speech components were not a concern in the early years (HOWATT, 1984; LEFFA, 2016, PAIVA, 2003). This comes as no surprise, as the beginning of second language teaching in formal classroom contexts aimed to prepare students to be proficient literature readers and translators (HOWATT, 1984). Advances in sciences and speech research, however, brought to life a real interest in the teaching of oral skills. Back in the later 1800s and early 1900s, technological and scientific developments such as the gramophone and the emergence of scientific tools such as phonetic alphabets gave rise to important changes in second language pedagogy. As a result, the teaching of speaking and, occasionally, pronunciation, started playing a central role in the classroom (CELCE-MURCIA et al., 2010).

Thanks to the scientific advances led by phoneticians, pronunciation teaching pedagogy started moving from an "intuitive-imitative approach" to an "analytic-linguistic approach", and these changes were more remarkable around the 1940s and 1950s (CELCE-MURCIA et al., 2010, p. 2). With the help of sound recording devices, it was possible to present models of speech samples and record learners' speech for analysis and feedback. At the same time, the use of some sort of phonetic alphabet, visual resources to demonstrate speech sound articulation, as well as minimal pair lists helped teachers to provide explicit instruction about how to produce and perceive second language speech.

Unquestionably, scientific and technological advances brought pronunciation teaching to the forefront of second language pedagogy, but pronunciation teaching soon received its share of criticism, which often resulted in excluding the pronunciation component from the second language teaching textbooks and classrooms. For example, the prevailing approach to second language teaching that has been highly influential over the past fifty years, the Communicative Approach, has initially eliminated pronunciation teaching from course books (CELCE-MURCA et al., 2010; LEVIS; SONSAAT, 2017), despite being an approach that emphasizes the teaching of oral skills.

Currently, there seems to be an attempt to reconcile pronunciation teaching with other oral skills in English course books distributed by major international publishers, as illustrated by three series often used to teach English in Brazil: Interchange (Cambridge University Press), English Files (Oxford University Press) and Global (Macmillan Education). When we observe course books designed to teach Brazilian Portuguese, we can see that pronunciation is beginning to be integrated in mainstream teaching materials, especially those designed with Spanish speakers in mind, as illustrated by recent publications such as the Brasil Intercultural series (Casa do Brasil), and a course book 
intended for pronunciation teaching, Curtindo os Sons do Brasil. Fonética do Português do Brasil Para Hispanofalantes (Lidel). Note, however, that both books have been printed by international publishers (Argentina and Portugal, respectively). This suggests that the scenario for pronunciation teaching in Brazil is beginning to change, but there is a long road ahead for the supporters of L2 pronunciation teaching.

Despite the tools provided by technology and by scientific developments, pronunciation teaching is still a case of love and hate in many English teacher education programs at Brazilian universities. As a result, it is common for English language teaching majors to conclude their degrees in Brazil without having ever reflected about pronunciation teaching or why it matters.

Studies on teachers' beliefs conducted in Brazil such as Buss $(2013,2016)$, Costa (2016) and Haus (2018) have shown that teachers generally report feeling uncomfortable with and unprepared to teach pronunciation. Teachers also report that they need a specific training course to learn how to teach pronunciation. Given this scenario, teachers who contributed to previous studies reported that they are often guided by intuitive notions of speech intelligibility in pronunciation teaching.

There is already a fair amount of research on the uses of technological resources for teaching pronunciation (e.g., BALDISSERA, 2013; CUCCHIARINI; STRIK, 2018; HARDISON, 2007; HAN, 2012, HINCKS, 2015; FOOTE; MCDONOUGH, 2017). As Pennington and Rogerson-Revell (2019, (p. 235-236) explain, technology-mediated pronunciation teaching "offers endless opportunities for repetition and imitation, instant responses and exposure to a wide variety of speech in the target language; it can also facilitate individualized learning" in addition to providing automated feedback.

The continuing interest in developing technological devices to provide support for pronunciation learning corroborate the fact that learners are interested in pronunciation, and the new digital tools provide an alternative path to work with pronunciation in a one-on-one basis. The individualized learning process often comes to supply a need for learning about an important language component that may not be addressed in the classroom for a number of reasons:

a) Teachers' beliefs (for example, pronunciation is picked up easily once a learner becomes proficient; pronunciation teaching hinders leaner's motivation; pronunciation teaching imposes native speakers' models and has a negative effect on learners' identity); 
b) The limitations of course books published by international publishing houses and adopted by some educational institutions, which must be used as a single pedagogical tool in classrooms;

c) The absence of introductory second language phonetics, phonology and pronunciation teaching courses as part of the curriculum of second language teaching programs at the university level and, consequently, the teachers' lack of knowledge and/or confidence on how to address pronunciation teaching in their classrooms.

The present volume brings three articles that address pronunciation teaching. The articles address key factors in pronunciation pedagogy, namely, the role of textbooks, the use of digital technology, and teachers' beliefs and practices.

Ribeiro, Cruz, Moraes and Brisolara analyze a course book series designed to teach Spanish to Brazilian learners in regular schools. The authors examine the scope of the pronunciation activities present in the book and conclude the article by suggesting pronunciation activities to enrich pronunciation teaching in regular schools.

Baldissera and Tumulo examined four commercial applications designed to teach English pronunciation. Based on literature in the fields of pronunciation pedagogy and Mobile Assisted Language Learning, the authors propose a framework to analyze pronunciation applications. Based on this framework, Baldissera and Tumolo discuss the affordances and limitations of each application when it comes to reaching the goal of helping learners develop intelligible pronunciation for successful communication.

Camargo and Kluge turn their attention to English teacher educators' beliefs and practices. They observed classes and interviewed teacher educators from two universities in order to unveil their beliefs and practices about the kind of knowledge pre-service teachers need to engage in the teaching of oral comprehension. The authors give special attention to beliefs and practices regarding pronunciation, as this factor surfaces as one important kind of knowledge, especially in the case where the pre-service students had low-proficiency levels.

Overall, the present issue puts together a collection of papers that unite both acquisitional studies and perspectives that orient language pedagogy (intelligibility, teaching materials, apps and teacher education). In the Brazilian Letras scenario, most researchers enrolled in Graduate Programs (either for their Masters' or PhD studies) or who are part of staff at Universities are also language teachers. Therefore, the disconnection of theory and practice is no longer attainable. For some, it still might linger 
on paper, but when it comes to practice, the pedagogical decisions of a teacher are always nuanced, complex and informed by different dimensions of knowledge, including that of theoretical (or academic) nature. Maybe, this is the time to blur divisionary boundaries and provide students and teachers with more opportunities of scientific exchange for them to evaluate whether this can help redesign their praxis. This issue also comprises of an invitation for more researchers to join the academic body in the field of L2 speech and Brazilian Applied Linguistics and voice their own perspectives so that more can be said about (and transformed in) the state of L2 speech research.

To conclude, we would like to express our gratitude to all authors who submitted their manuscript and trusted Revista $X$ as a venue for their work. We extend our gratitude to all ad hoc reviewers who carefully read the submitted manuscripts and provided valuable feedback to the authors. We are also thankful to the staff from Seção de Apoio às Publicações Científicas Periódicas at UFPR for the thorough editing services provided to Revista $X$.

We hope these papers bring about new reflections and transformation, while giving strength for teachers, students and researchers to position themselves in times like these, when our profession has been so discredited in the national political scenario, reflecting harshly in educational policies and teacher education programs. Despite the hardship, we hope our readers find some content through these pages and that this resonates in critical attitudes favoring science, knowledge, education and democracy. May you all have an enriching experience with this collection.

\section{Acknowledgments}

I (Alison) would like to thank Rosane, Bira and Pedro for promptly accepting the invitation to prepare this issue with Revista $X$. I feel blessed to be able to count on their partnership.

\section{REFERENCES}

ALBANO, E. C. O gesto e suas bordas - esboço da Fonologia Acústico-Articulatória para o português brasileiro. Campinas: FAPESP/Mercado de Letras, 2001.

BALDISSERA, L. G. App Resources for Developing English Pronunciation: A Focus on Mobile Technology. 2020. 268 f. Dissertação (Mestrado) - Programa de Pósgraduação em Inglês: Estudos Linguísticos e Literários, Universidade Federal de Santa Catarina, Florianópolis, 2020. 
BARDOVI-HARLIG, K. Pragmatic determinants of English sentence stress. Bloomington: Indiana University Linguistics Club, 1986.

BEST, C. T. A direct-realist view of cross-language speech perception. In: STRANGE. W. (Ed.). Speech Perception and Linguistic Experience: Issues in Cross-Language Research. Timonium: York Press, 1995. p. 171-204.

BEST, C. T.; TYLER, M. D. Nonnative and second-language speech perception: commonalities and complementarities. In: BOHN, O.-S.; MUNRO, M. J. (eds.). Language Experience in Second Language Speech Learning - in honor of James Emil Flege. Amsterdam: John Benjamins Publishing Company, 2007, p. 13-34.

BØHN, H.; HANSEN, Thomas. Assessing pronunciation in an EFL context: Teachers' orientations towards nativeness and intelligibility. Language Assessment Quarterly, v.14, n. 1, p. 54-68, 2017.

BROWMAN, C.; GOLDSTEIN, L. Articulatory Phonology: an overview. Phonetica, v. 49, p. $155-180,1992$.

BROWMAN, C.; GOLDSTEIN, L. Towards an Articulatory Phonology. Phonology Yearbook, v. 3, p. 219-252, 1986.

BUSS, L. Beliefs and practices of Brazilian EFL teachers regarding pronunciation. Language Teaching Research, [s.1.], v. 20, n. 5, p. 619-637, 2016.

BUSS, L. The Role of Training in Shaping Teacher Cognition Related to L2 Pronunciation. Ilha do Desterro, Florianópolis, v. 70, n. 3, p. 201-226, 2017.

CELCE-MURCIA, M.; BRINTON, D. M.; GOODWIN, Janet M.. Teaching Pronunciation: A Course Book and Reference Guide. 2. ed. Cambridge: Cambridge University Press, 2010.

COLANTONI, L.; STEELE, J.; ESCUDERO, P. Second Language Speech - Theory and Practice. Cambridge: Cambridge Scholars Publishing, 2015.

COSTA, B. C. A. Pronunciation teaching is not a one-size-fits-all endeavor: EFL teachers' beliefs and classroom. 2016. 112 f. Dissertação (Mestrado) - Programa de Pósgraduação em Inglês: Estudos Linguísticos e Literários, Universidade Federal de Santa Catarina, Florianópolis, 2016. 
CUCCHIARINI, C.; STRIK, Helmer. Automatic speech recognition for second language pronunciation training. In: KANG, Okim; THOMAON, Ron I.; MURPHY, John M. The Routledge Handbook of Contemporary English Pronunciation. Londres: Routledge, 2018. p. 556-569.

CUMMING, R. E. Speech rhythm: the language-specific integration of pitch and duration. 2010. 268 f. Tese (Doutorado em Filosofia) - Downing College. Cambridge Universidade de Cambridge, Cambridge, 2010. Disponível em: https://www.repository. cam.ac.uk/handle/1810/228685. Acesso em: 27 mar. 2021.

DANCY, J. Epistemologia contemporânea. Cambridge, MA: Harvard University Press, 1985.

DERWING, T.; MUNRO, M. Putting accent in its place: Rethinking obstacles to communication. Language Teaching, v. 42, p. 1-15, 2009.

DERWING, T.; MUNRO, M. The interface of teaching and research: What type of pronunciation instruction should L2 learners expect? In: LUCHINI, P.; GARCÍA JURADO, M.A.; ALVES, U. (Eds.). Fonética y fonología: Articulación entre enseñanza e investigación, Mar del Plata: Biblioteca Central Universidad Nacional de Mar del Plata, 2015, p. 14-26.

DERWING, T.; MUNRO, M.; WIEBE, G. Evidence in favor of a broad framework for pronunciation instruction. Language Learning, v. 48, n. 3, p. 393-410, 1998.

FLEGE, J. E. Second Language Speech Learning: Theory, findings, and problems. In: STRANGE, W. (ed.). Speech perception and linguistic experience: issues in crosslanguage research. Timonium, MD: York Press, 1995, p. 233-277.

FLEGE, J.; BOHN, O. The Revised Speech Learning Model (SLM-r). In: WAYLAND, R. (Ed.). Second Language Speech Learning: Theoretical and Empirical Progress. Cambridge: Cambridge University Press, 2021. p. 03-83.

FOOTE, J. A.; MCDONOUGH, K. Using shadowing with mobile technology to improve L2 pronunciation. Journal of Second Language Pronunciation, [s.1.], v. 3, n. 1, p. 34$56,2017$.

FOWLER, C. An event approach to the study of speech perception from a direct-realist perspective. Journal of Phonetics, v. 14, p. 3-28, 1986.

GARCÍA JURADO, M. A.; ARENAS, M. La Fonética del Español; Análisis e investigación de los sonidos del habla. Buenos Aires: Quórum/UMSA, 2005. 
GORDON, J.; DARCY, I.; EWERT, D. Pronunciation teaching and learning: Effects of explicit phonetic instruction in the L2 classroom. In: LEVIS, J.; LEVELLE, K. (Eds.), Proceedings of the 4th pronunciation in second language learning and teaching conference. Ames, IA: Iowa State University, 2013, p. 194-206.

HAHN, L. Primary stress and intelligibility: Research to motivate the teaching of suprasegmentals. TESOL Quarterly, v. 38, n. 2, p. 201-203, 2004.

HALLIDAY, M. Halliday's introduction to functional grammar. New York: Routledge, 2014.

HAN, J. Emerging technologies: Robot assisted language learning. Language Learning \& Technology, v. 16, n. 3, p. 1-9, 2012.

HARDISON, D. M. The visual element in phonological perception and learning. In. PENNINGTON, Martha C. Phonology in context. Palgrave Macmillan, London, p. 135$158,2007$.

HAUS, C. Ensino de pronúncia sob a perspectiva do inglês como língua franca: crenças e práticas de professores de inglês do CELIN-UFPR. 2018. 171 f. Dissertação (Mestrado) - Programa de Pós-graduação em Letras, Setor de Ciências Humanas, Universidade Federal do Paraná, Curitiba, 2018.

HINCKS, R. Technology and learning pronunciation. In: LEVIS, Marnie Reeds \& John. The Handbook of English Pronunciation. Pondicherry: Wiley-Blackwell, p. 505-519, 2015.

HOWATT, A. P. R., A History of English Language Teaching. Oxford: Oxford University Press, 1984, 394 pp.

IOUP, G.; BOUSTAGUI, E.; EL TIGI, M.; MOSELLE, M. (1994). Reexamining the critical period hypothesis: A case study of successful adult SLA in a naturalistic environment. Studies in Second Language Acquisition, v. 16, p. 73-98.

ISAAC, T.; TROFIMOVICH, P. Deconstructing comprehensibility. Studies in Second Language Acquisition, v. 34, p. 475-505, 2012.

JACKSON, F. Perception. Cambridge: Cambridge University Press, 1977.

JACKSON, F. Representative realism. In: DANCY, J.; SOSA, E.; STEUP, M. (eds.). A companion to epistemology. Malden: Blackwell, 2010, p. 702-705. 
KANG, O.; JOHNSON, D. The roles of suprasegmental features in predicting English oral proficiency with an automated system, Language Assessment Quarterly, v. 15, p. $1-19,2018$.

KANG, O.; RUBIN, D.; PICKERING, L. Suprasegmental measures of accentedness and judgments of language learner proficiency in oral English. The Modern Language Journal, v. 94, n. 4, p. 554-566, 2010.

LEFFA, V. J. Língua estrangeira: ensino e aprendizagem. Pelotas: EDUCAT, 2016.

LENNEBERG, E. Biological foundations of language. New York: Wiley, 1967.

LEVELT, W. Speaking: from Intention to Articulation. Cambridge, Massachusetts: The MIT Press, 1989.

LEVIS, J. Changing contexts and shifting paradigms in pronunciation teaching. TESOL Quarterly, v. 39, n. 3, p. 369-377, 2005.

LEVIS, J. Intelligibility, oral communication, and the teaching of pronunciation. Cambridge: Cambridge University Press, 2018.

LEVIS, J. M., \& SONSAAT, S. Pronunciation teaching in the early CLT era. In O. Kang, R. Thomson \& J. Murphy (Eds.), The Routledge handbook of English pronunciation, (pp. 267-283). Routledge, 2017.

LI, A.; POST, B. L2 acquisition of prosodic properties of speech rhythm: evidence from L1 Mandarin and German Learners of English. Studies in Second Language Acquisition, v. 36, n. 2, p. 223-255, 2014. Available: https://doi.org/10.1017/S0272263113000752. Access: 12 May, 2021.

LOWE, J. Indirect perception and sense data. The Philosophical Quarterly, v. 31, n. 125, p. 330-342, 1981.

LUCHINI, P. (2021). Mediciones de ritmo, grado de acento extranjero y fluidez discursiva: un estudio evaluativo con estudiantes argentinos de L2. Cuadernos de Lingüística, 2, 1, 1-21. DOI: 10.25189/2675-4916.2021.V2.N1.ID332., 2, 1, ID332

LUCHINI, P.; KENNEDY, S. Exploring sources of unintelligibility between non-native English speakers: A case study. The International Journal of English and Literature, v. 4, n. 3, p. 79-88, ISSN: 2141-2626. 
MCNERNEY, M.; MENDELSOHN, D. Suprasegmentals in the pronunciation class: Setting priorities. In: AVERY, P.; EHRLICH, S. (Eds.). Teaching American English pronunciation. Oxford: Oxford University Press, 1992, p. 185-196.

MOYER, A. Ultimate attainment in L2 phonology: The critical factors of age motivation and instruction. Studies in Second Language Acquisition, v. 21, 81-108, 1999.

MUNRO, M. J.; DERWING, T. M. Modeling perceptions of the accentedness and comprehensibility of 12 speech: the role of speaking rate. Studies in Second Language Acquisition, v. 23, n. 4, p. 451-468, 2001.

MUNRO, M.; DERWING, T. Foreign accent, comprehensibility, and intelligibility in the speech of second language learners. Language Learning, v. 49, n. 1, p. 285-310, 1999.

ORDIN, M.; POLYANSKAYA, L. Acquisition of speech rhythm in a second language by learners with rhythmically different native languages. The Journal of the Acoustical Society of America, v. 138, n. 2, p. 533-544, 2015.

ORION, G. Pronouncing American English: Sounds, stress, and intonation (2nd ed.). Boston: Heinle \& Heinle, 1997.

PAIVA, V. L. M. O. A LDB e a legislação vigente sobre o ensino e a formação de professor de língua inglesa. In: STEVENS, Cristina Maria Teixeira; CUNHA, Maria Jandyra Cavalcanti. Caminhos e colheitas: ensino e pesquisa na área de inglês no Brasil. Brasília: Unb, 2003. p. 53-84.

PANZACHI H. A.; LUCHINI, P. La incidencia del emplazamiento del acento nuclear en los distintos componentes de la comprensión auditiva en un contexto de inglés como lengua extranjera. In: LUCHINI, P.; ALVES, U. (Eds.). Cuestiones del Lenguaje: desarrollo de lenguas extranjeras, enseñanza y traducción. Mar del Plata: Universidad Nacional de Mar del Plata, 2020 (Biblioteca Central). Libro digital, PDF, Archivo Digital: descarga y online. ISBN 978-987-544-956-5, 2020, p. 32-45.

PENNIngton, M. C.; ROGERSON-REVELL, P. English Pronunciation Teaching and Research: contemporary perspectives. Research and practice in applied linguistics series. Basingstoke: Palgrave Macmillan, 2019.

PEROZZO, R. V. Sobre as esferas cognitiva, acústico-articulatória e realista indireta da percepção fônica não nativa: para além do PAM-L2. Tese (Doutorado em Letras). Porto Alegre: Universidade Federal do Rio Grande do Sul, 2017. 
SAITO, Y.; SAITO, K. Differential effects of instruction on the development of second language comprehensibility, word stress, rhythm, and intonation: The case of inexperienced Japanese EFL learners. Language Teaching Research, v. 21, n. 5, p. 589-608, 2017.

SILVAJUNIOR, L. J. da; BARBOSA, P. A. Speech rhythm of English as L2: an investigation of prosodic variables on the production of Brazilian Portuguese speakers. Journal of Speech Sciences, Campinas, SP, v. 8, n. 2, p. 37-57, 2020. DOI: 10.20396/joss.v8i2.14996. Disponível em: https://econtents.bc.unicamp.br/inpec/index.php/joss/article/view/14996. Acesso em: 17 aug. 2021.

SCOVEL, T. Differentiation, recognition, and identification in the discrimination of foreign accents. In: ARCHIBALD, J. (Ed.), Phonological acquisition and phonological theory. Hillsdale, NJ: Lawrence Erlbaum, 1995, p. 169-181.

TAJIMA, K.; PORT, R.; DALBY, J. Effects of temporal correction on intelligibility of foreign-accented English. Journal of Phonetics, v. 25, p. 1-24, 1997.

THOMSON, R. I.; DERWING, T. M. The Effectiveness of L2 Pronunciation Instruction: A narrative Review. Applied Linguistics, v. 36, n. 3, p. 326-344, 2015.

TROFIMOVICH, P.; ISAACS, T. Disentangling accent from comprehensibility. Bilingualism. Language and Cognition, v. 15, n. 4, p. 905-916, 2012.

WINTERS, S.; O'BRIEN, M. Perceived accentedness and intelligibility: The relative contributions of F0 and duration. Speech Communication, v. 55, n. 3, p. 486-507, 2013. 